
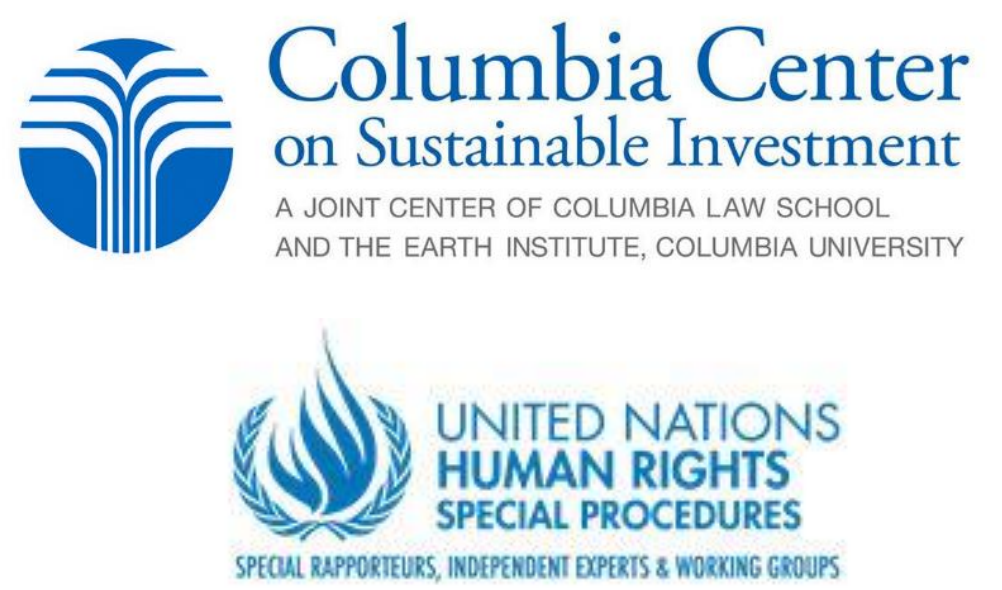

Working Group on the issue of human rights and

transnational corporations and other business enterprises

\title{
Impacts of the International Investment Regime on Access to Justice
}

\author{
Roundtable Outcome Document
}

September 2018 


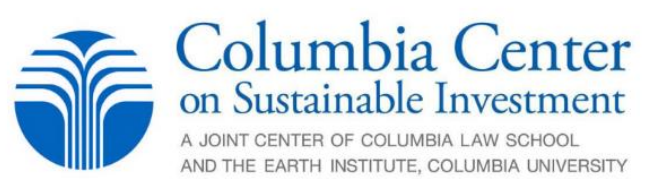

The Columbia Center on Sustainable Investment (CCSI), a joint center of Columbia Law School and the Earth Institute at Columbia University, is the only university-based applied research center and forum dedicated to the study, practice, and discussion of sustainable international investment worldwide. Its mission is to develop practical approaches for governments, investors, communities, and other stakeholders to maximize the benefits of international investment for sustainable development, while minimizing the potential harms that can accompany large-scale investment projects. CCSI works at the nexus of international investment law and human rights law, and at the project-level and contract-level on the human rights impacts of investment projects. We conduct robust research; develop accessible resources and tools; convene nuanced dialogue; and provide trainings, advisory support, and technical input.

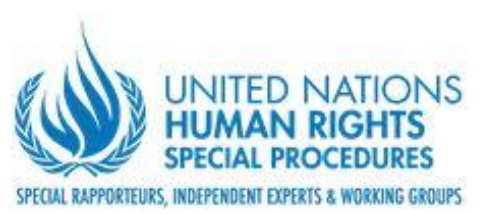

The UN Working Group on the issue of human rights and transnational corporations and other business enterprises ("UN Working Group on Business and Human Rights"), established by the Human Rights Council in June 2011, consists of five independent experts of balanced geographical representation. Upon establishment, the Human Rights Council requested the Working Group to pursue a range of objectives, including: implementation of the Guiding Principles on Business and Human Rights; exploration of options for enhancing access to effective remedy for business-related human rights violations; development of regular dialogue with all relevant actors; and guidance of the annual United Nations Forum on Business and Human Rights. In June 2017 at its thirty-fifth session (in resolution 35/7), the Human Rights Council extended the Working Group's mandate for a period of three years. 


\section{Background}

On October 18, 2017, the UN Working Group on Business and Human Rights (Working Group) and the Columbia Center on Sustainable Investment (CCSI) hosted a one-day roundtable on the impacts of the international investment regime on access to justice for investment-affected individuals and communities.

Held at Columbia University in New York, the roundtable brought together 32 individuals from civil society organizations, communities affected by investments at the heart of investor-state claims, governments, academia, donor organizations, UN mandate holders, and other stakeholder groups. The roundtable provided an opportunity for participants to: (i) explore and assess the specific impacts of international investment agreements and investor-state dispute settlement on access to justice, both within and outside the investment regime; (ii) discuss and analyze options for reform of the international investment regime and improvement of human rights enforcement mechanisms to determine whether they address the specific impacts explored; and (iii) identify a preliminary set of recommendations to address implications of the current investment regime for access to justice. Following the roundtable, key takeaways from the discussion were discussed during a session at the $6^{\text {th }}$ UN Forum on Business and Human Rights on November 29th $2017 .^{1}$

For the Working Group, the roundtable constituted the first of several consultations it will be holding as part of its efforts to provide advice and guidance to states on how to "maintain adequate policy space to meet their human rights obligations when pursuing business-related policy objectives with other states or business enterprises" under Principle 9 of the UN Guiding Principles on Business and Human Rights. The roundtable took place shortly after the Working Group presented its 2017 report to the UN General Assembly. ${ }^{2}$ The report examines the issue of effective remedies from the perspectives of rights holders and proposes that remedial mechanisms should be responsive to the diverse experiences and expectations of rights holders. Discussions at the roundtable built upon the issues examined in the report.

For CCSI, exploring and addressing the implications of the investment regime for access to justice forms a critical component of two projects the Center is currently undertaking: the first seeks to examine the impact of investor-state arbitration on access to justice in the context of land-based investments, while the second is geared toward advancing new thinking on international investment agreements, including ways of aligning these agreements with sustainable development objectives. The takeaways from this roundtable will inform CCSI's work on these issues. CCSI also aims to use roundtable discussions to inform input into investor-state arbitration reform processes currently underway in national, plurilateral, and multilateral fora.

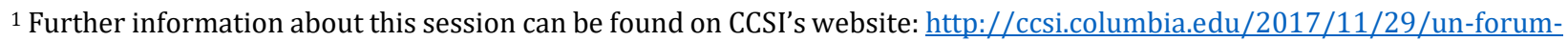
on-business-and-human-rights-session-on-realizing-access-to-remedy-implications-of-the-international-investment-

regime/.

2 Report of the Working Group on the issue of human rights and transnational corporations and other business enterprises, UN Doc A/72/162 (July 18, 2017). Available at http://ap.ohchr.org/documents/dpage_e.aspx?si=A/72/162. More information on the Working Group is available on their homepage:

www.ohchr.org/EN/Issues/Business/Pages/WGHRandtransnationalcorporationsandotherbusiness.aspx.
} 


\section{Acknowledgments}

This document was written by Michelle Chan and Kanika Gupta, with support from Jesse Coleman, Kaitlin Cordes, and Lise Johnson. The document was reviewed by Surya Deva and Ulrik Halsteen. The authors would like to thank Sam Szoke-Burke, Brooke Skartvedt Güven, and Ulrik Halsteen for their help in organizing the October 18 roundtable; and Arturo Sanchez Brown, Juana Martinez, Daniel Morales, Paola Patarroyo, and Claudene Petricca for their note-taking support during the event. We are grateful to the UN Working Group on Business and Human Rights, and in particular to Surya Deva, the then Chair of the Working Group, for collaborating with CCSI on the roundtable. The coorganizers express their gratitude to Open Society Foundations, the Rockefeller Brothers Fund, and the Swiss Agency for Development and Cooperation for their generous support for this event.

The roundtable discussion took place under Chatham House Rule, and this outcome document is therefore drafted without attribution. 


\section{Table of Contents}

The International Investment Regime and Access to Justice .......................................................... 6

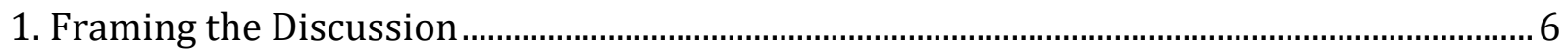

(a) The International Investment Regime....................................................................... 6

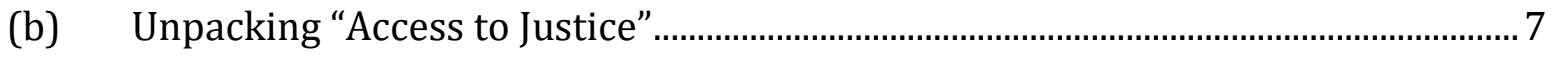

2. Actual or Potential Impacts of the Investment Regime ........................................................ 8

Investor-state arbitration is exclusionary ……………….................................................. 10

Stalling, ending, or otherwise undermining remedies obtained by rights holders ........ 11

Victimization and criminalization of community members ................................................ 12

Allocation of state resources................................................................................................. 13

Regulatory chill and other disincentives............................................................................. 13

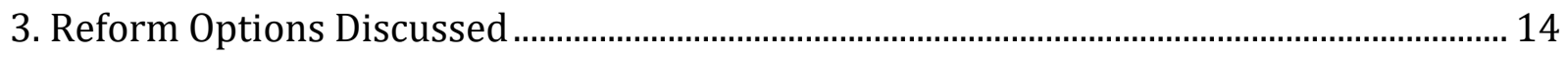

Explore informed alternatives to the current approach to investment protection........ 15

Reform investment treaty standards................................................................................. 15

Reform investor-state arbitration..................................................................................... 17

Empower rights holders .................................................................................................... 18

Develop and implement effective monitoring strategies...................................................... 19

Enhance human rights enforcement mechanisms ............................................................. 20

Break down silos..................................................................................................................... 20

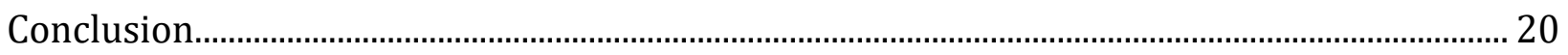




\section{The International Investment Regime and Access to Justice}

This outcome document synthesizes key takeaways from a roundtable discussion that sought to explore the impacts of the international investment regime on access to justice for investmentaffected individuals and communities. Drawing on the plenary and breakout discussions that took place during this one-day, multi-stakeholder roundtable, the document pulls together and highlights central themes that ran throughout the discussion. It first outlines core concepts and introductory points that framed much of the roundtable discussion. The second section provides an overview of impacts of the investment regime on access to justice highlighted by roundtable participants. The third section outlines recommendations discussed by participants regarding reform of the investment regime and strengthening of human rights enforcement. While these recommendations focus in particular on addressing the impacts of the investment regime on access to justice, they are relevant to broader discussions regarding reform and improvement of both the investment and human rights regimes.

\section{Framing the Discussion}

\section{(a) The International Investment Regime}

The international investment regime consists of more than 3,300 investment treaties, including both bilateral investment treaties (BITs) and free trade agreements (FTAs) with investment chapters. These agreements are typically asymmetric in nature: they establish a range of protections for covered investors, usually multinational enterprises (MNEs), which entail obligations for states parties, while not imposing any direct human rights obligations on investors. State obligations under these agreements can, in most cases, be enforced by means of investor-state arbitration (which is often referred to as investor-state dispute settlement, or ISDS), which provides MNEs with unique access to remedy at the international level. To date, investors have lodged more than 800 known treaty-based investor-state claims. MNEs have relied upon investor-state arbitration to challenge state decisions, policies, and measures adopted in pursuit of public interest objectives, including, for example: legislation requiring plain packaging for tobacco products; regulations adopted for protection of the environment (including water sources); court decisions holding companies liable for harms to private individuals and communities; and measures adopted to address local opposition to investment projects.

Largely due to the concerns regarding the high costs of investor-state arbitration and the restrictions placed by the investment regime on the right - or duty - of states to regulate in the public interest, a range of stakeholders have been advocating for reform of the current investment regime. A number of states have already begun to take action: some have sought to revise investment treaty standards to better protect their ability to regulate; others have advanced new approaches to investment promotion, protection, and dispute settlement; others still have withdrawn from the international investment regime entirely. 
While these reforms have been the subject of broad and ongoing public debate for several years, the actual or potential impacts of the international investment regime on access to justice for investmentaffected individuals and communities have received less attention in discourse and action on reform at the global, regional, and national levels.

\section{(b) Unpacking "Access to Justice"}

Access to justice and the right to an effective remedy form a core component of state obligations under human rights law. ${ }^{3}$ Providing equal access to justice for all is also a stated target of the universally adopted Sustainable Development Goals. In the context of business activities, ensuring access to effective remedy has been deemed essential, forming one of the three pillars of the UN Guiding Principles on Business and Human Rights (UN Guiding Principles). Yet, victims of businessrelated human rights abuses often face both legal and practical barriers to accessing justice and obtaining effective remedies. In recent years, several initiatives have sought to highlight and address these barriers. In November 2014, the Office of the UN High Commissioner for Human Rights (OHCHR) launched its Accountability and Remedy Project, which sought solutions to overcome obstacles undermining the effectiveness of judicial mechanisms in achieving corporate accountability and access to remedy in the context of business-related human rights abuses. ${ }^{4}$ The project led to the publication of guidance for states on improving judicial mechanisms at the domestic level. ${ }^{5}$ Addressing barriers to accountability and effective remedy for business-related human rights abuses has also been central to discussions on the development of an international legally binding instrument to regulate the activities of transnational corporations and other business enterprises with respect to human rights. ${ }^{6}$

\footnotetext{
${ }^{3}$ For this meeting, we focus primarily on access to justice as a broad concept that includes access (and the right) to effective remedy. Access to justice and access/the right to (effective) remedy are slightly different concepts that have sometimes been used interchangeably. Both the "right to an effective remedy" and "effective access to justice" have been codified in human rights treaties (the International Covenant on Civil and Political Rights - ICCPR - and the Convention on the Rights of Persons with Disabilities - CRPD - respectively), although the former has more conceptual clarity as a right imposing both procedural and substantive duties on States. Access to justice, on the other hand, has been described as more narrow, more broad, or essentially comparable to the right to effective remedy. For a further discussion of the terminology, see Report of the Working Group on the issue of human rights and transnational corporations and other business enterprises, UN Doc A/72/162 (July 18, 2017), paras 13-17.

4 See UN OHCHR Accountability and Remedy Project at http://www.ohchr.org/EN/Issues/Business/Pages/OHCHRstudyondomesticlawremedies.aspx>.

${ }^{5}$ Report of the UN High Commissioner for Human Rights, "Improving Accountability and Access to Remedy for Victims of Business-Related Human Rights Abuse," UN Doc A/HRC/32/19 (May 2016) < http://www.ohchr.org/Documents/Issues/Business/DomesticLawRemedies/A HRC 3219 AEV.pdf>; Improving accountability and access to remedy for victims of business-related human rights abuse: Explanatory Notes for Guidance, UN $\quad$ Doc $\quad$ A/HRC/32/19/Add.1 $\quad$ (May 2016 ) http://www.ohchr.org/Documents/Issues/Business/DomesticLawRemedies/A HRC 3219 Add.1 AEV.pdf>.

${ }^{6}$ Open-ended intergovernmental working group on transnational corporations and other business enterprises with respect to human rights <http://www.ohchr.org/EN/HRBodies/HRC/WGTransCorp/Pages/IGWGOnTNC.aspx>. Since the roundtable took place, the following has been published: a paper outlining "Elements for the Draft Legally Binding Instrument on Transnational Corporations and Other Business Enterprises with Respect to Human Rights" was published, <http://www.ohchr.org/Documents/HRBodies/HRCouncil/WGTransCorp/Session3/LegallyBindingInstrumentTNCs OB Es.pdf>; and a zero draft of a legally binding instrument to regulate, in international human rights law, the activities of transnational corporations and other business enterprises <https://www.ohchr.org/Documents/HRBodies/HRCouncil/WGTransCorp/Session3/DraftLBI.pdf>.
} 
The Working Group has also given more specific attention to this issue recently. Access to effective remedy was the theme of the Working Group's 2017 report, which was presented to the UN General Assembly just prior to the October 18 roundtable. ${ }^{7}$ It was also the overall theme of the 2017 UN Forum on Business and Human Rights (27-29 November 2017), which the Working Group guides and chairs.

To help frame the roundtable discussion, one participant provided an overview of the Working Group's 2017 report, and highlighted the differing conceptual approaches adopted by the human rights community in referring to access to remedy, justice, and accountability. The participant explained that the Working Group's report seeks to provide greater conceptual clarity regarding the different terms used in the literature and discourse on access to remedy. The report also underscores the idea that rights holders should be central to the remedy process, and makes the case that the right to remedy should be the lens through which all three pillars of the UN Guiding Principles should be seen. According to the report, the right to an effective remedy has two core elements: process and outcome. In other words, having merely access to effective remedy is not sufficient without an effective remedy at the end of the process. ${ }^{8}$

The Working Group's report is grounded in the notion that rights holders must be central to the entire remedy process, as they are the ones who suffer harm from business-related human rights abuses. To this end, rights holders must not be seen as a single group, but diverse in background and experiences, with different expectations regarding access to remedy and the meaning of "effective" remedy. The report points out that no single remedy makes a remedy effective in every case, and that a full range of remedies should be available to rights holders at the same time (i.e. "bouquet of remedies"). ${ }^{9}$ These remedies should be deterrent, preventative, and redressive, and can be located in diverse settings. ${ }^{10}$ The Working Group's report also highlights that rights holders currently do not inform the remedy process, and often fear criminalization when seeking remedies. ${ }^{11}$ As noted further below, during the roundtable discussion that followed these introductory remarks, several roundtable participants shared stories of specific instances of criminalization or repression of community members and their allies seeking justice in the context of investment-related human rights abuses.

\section{Actual or Potential Impacts of the Investment Regime}

The first roundtable session took stock of the actual and potential impacts of investment treaties and investor-state arbitration on access to justice for investment-affected rights holders, with participants examining impacts of the investment regime on access to justice both within and outside the regime itself. Representatives of two communities affected by investments that gave rise to

\footnotetext{
${ }^{7}$ Report of the Working Group on the issue of human rights and transnational corporations and other business enterprises, UN Doc A/72/162 (July 18, 2017). Available at http://ap.ohchr.org/documents/dpage_e.aspx?si=A/72/162.

8 Ibid, paras. 13-17.

9 Ibid, paras. 38-54.

10 Ibid, para. 7.

11 Ibid, paras. 18-25.
} 
investor-state claims began the discussion by sharing their views on the specific investment impacts experienced or feared by these communities, their concerns about investor-state arbitration, and their efforts to seek justice for investment-related human rights violations and abuses.

The first presentation focused on an indigenous community in South America and the effects of a mining project led by a foreign investor. Two community representatives explained how community members had been excluded from the entire investment process, from the negotiation stage to processes relating to the investor-state claim. Massive protests erupted when the company was given a license to operate by the state without sufficient consultation with the surrounding communities. The community representatives explained that many people who took part in the protests were unfairly detained and fined. After the government subsequently revoked permissions related to the proposed investment, the foreign investor brought an investor-state claim under an applicable investment treaty. Community representatives at the roundtable noted that their community continued to encounter frustrations during the investor-state arbitration process. The representatives explained that, while they were able to file a submission as amicus curiae, this did not equate to a meaningful form of participation in the dispute settlement process. Noting that the investor-state arbitration regime excluded them entirely, one representative asserted: "if you believe amicus works, that is false." The representative explained that, to present as an amicus, they had to have a neutral position, which felt impossible. According to this same representative, the investorstate process did not allow indigenous peoples to meaningfully participate, and did not protect them or allow the affected communities to obtain a remedy in an effective manner. A community representative also highlighted that, despite the profound and direct impacts of the claim on the lives of community members, the dispute was determined in an environment that was not conducive to the community's participation. The participant noted: "[t]hey were talking about my land, my territory, my life, my existence, but I didn't have a voice." The representatives also noted that some community members affected by the investment and related claim were not even aware of the process taking place, or of the implications that might result from the tribunal's determination. A participant pointed out that community representatives were disheartened by the investment and dispute process, as they were left out of every stage of decision-making around the land and natural resources that they consider their sanctuary, their source of medicine, their place to pray, and, in some sense, their life.

The second presentation related to another mining project in a different South American country. Two community representatives explained that the people who stood to be affected by the project were never consulted, and that community members and civil society advocates involved in opposing the project were subjected to violent repression by groups hired by the company, and were also criminalized. They noted that one of their fellow community members had gone through dozens of trials, whereas the company, which had attacked their way of life and their human rights, had not been brought to account. They explained that, despite the wrongful conduct on the part of the investor, the investor ultimately recovered damages in its successful investor-state claim. The community representatives underscored the unjust nature of this outcome, and expressed disbelief, noting: "it's not possible that they then win money after having created so much harm in our territory and amongst our people." The community representatives criticized the deeply exclusionary nature 
of the international investment regime: not only did it fail to adequately consider the harms suffered by communities, but in this case, the regime validated violations of human, environmental, and constitutional rights.

Following these remarks, participants proceeded to discuss the ways in which investment treaties and investor-state arbitration can affect rights holders' access to justice within and outside the investment regime. During the course of the discussion, participants examined different judicial and non-judicial means of accessing justice that are available to investment-affected rights holders, and the ways in which the international investment regime may restrict, undermine, or otherwise affect these means of accessing justice. Participants acknowledged from the outset that certain implications of the investment regime for access to justice may be more difficult to identify and track than others, particularly given the continuing lack of transparency that permeates the investment regime at the treaty and contract or project levels. Improvement of transparency and monitoring efforts could help to clarify some of these implications, along with related solutions.

\section{Investor-state arbitration is exclusionary}

Participants agreed that, within the investment law framework, opportunities for individuals and communities affected by investment to access justice do not currently exist. Investor-state arbitration does not allow investment-affected rights holders to meaningfully participate in proceedings or intervene as third parties. Not only is investor-state arbitration exclusionary, it also is often not transparent, meaning that, in many cases, little or no information regarding claims and awards is released to investment-affected rights holders, or to the public more generally. Even if information is available, it is often in English, which may not be (widely) spoken within the interested or affected communities.

While investment-affected rights holders can, in some cases, seek to make submissions to investorstate tribunals as amicus curiae, participants agreed that this form of purported participation provides neither an effective nor practical means of accessing justice for either state violations or company abuses exacerbated or caused by international investments. Participants with direct knowledge or experience of the amicus process noted that communities are generally far removed from investor-state arbitration proceedings, and that participation as amicus curiae is complex, resource intensive, and lacks sufficient space and support for investment-affected rights holders to meaningfully voice concerns or seek to assert their rights. ${ }^{12}$ Moreover, access to this form of participation is granted by investment tribunals, which have the discretion to determine whether to accept or reject submissions as amicus curiae. A number of participants noted that, in many cases, tribunals have either rejected applications to file amicus submissions, or they have given limited consideration to the information put forward in accepted submissions. ${ }^{13}$

\footnotetext{
12 See also Report of the Special Rapporteur of the Human Rights Council on the rights of indigenous peoples on the impact of international investment and free trade on the human rights of indigenous peoples, UN Doc A/70/301 (August 7, 2015) <http://unsr.vtaulicorpuz.org/site/images/docs/annual/2015-annual-ga-a-70-301-en.pdf>.

13 For discussion of community perspectives in investor-state claims, see Lorenzo Cotula and Mika Schröeder , "Community Perspectives in Investor-State Arbitration," International Institute for Environment and Development (June 2017) <
} 
Several participants also noted that information asymmetries undermine the ability of investmentaffected rights holders to assert their rights in the context of investor-state disputes. Due to challenges investment-affected rights holders face in accessing information about the content of the law (which arises from continued lack of transparency in the investor-state arbitration system generally, language barriers, and other challenges), and challenges in accessing information about the specific disputes, even those granted permission to participate as amicus curiae may face significant hurdles in ensuring their participation is effective.

These issues are relevant not just for outcomes of specific disputes, but also for how cases are understood, and how investment "law" develops. Barriers to participation limit how the investments, conflicts and concerns are recounted to tribunals and subsequently reflected in arbitral awards, the formal legal records of the cases, and documents which may have persuasive effect in other, similar disputes. Exacerbating problems created by limited inputs into proceedings is the fact that the facts and law as reflected in the outputs - the awards - may be made public only in parts, causing those awards to reflect a record of incidents, causes, and effects that are very different from what affected communities might have perceived and experienced. One participant provided the example of Copper Mesa v. Ecuador, ${ }^{14}$ where even the award itself was heavily redacted in areas that described the company's activities.

Beyond investor-state arbitration, participants also noted the exclusionary nature of the investment treaty negotiation process itself. There is little or no opportunity for input from, or meaningful consultation of, those whose rights may be affected by these treaties. This may be one reason why investor-state arbitration itself has been designed to be so asymmetrical.

\section{Stalling, ending, or otherwise undermining remedies obtained by rights holders}

Participants noted that the threat of investor-state arbitration, or actual arbitration proceedings, might have the impact of directly stalling, ending, or otherwise undermining remedies or other justice measures obtained by rights holders in other fora, such as domestic courts. Roundtable participants discussed, for example, the lengthy series of claims involving Chevron, Ecuador, and the Lago Agrio plaintiffs, in which the company sought to obtain interim measures (and ultimately an award) precluding enforcement of domestic awards obtained by affected communities for environmental harms caused by an investment. ${ }^{15}$

http://pubs.iied.org/12603IIED/>. See also CCSI, Submission as an 'Other Person' in Bear Creek Mining Corporation v. Peru (July 9, 2016) <http://ccsi.columbia.edu/files/2016/08/Bear-Creek-v-Peru-ARB-14-21-Written-Submission-CCSI.pdf>.

14 Copper Mesa Mining Corporation v. Republic of Ecuador (PCA No. 2012-2), Award (March 15, 2016) $<$ https://www.italaw.com/cases/4206>.

15 Chevron Corporation and Texaco Petroleum Corporation v. The Republic of Ecuador (II) (PCA Case No. 2009-23). For a summary of the Lago Agrio claims, see Business \& Human Rights Resource Centre, "TexacoChevron Lawsuits re Ecuador," $<$ https://business-humanrights.org/en/texacochevron-lawsuits-re-ecuador>. Chevron also brought another investorstate claim against Ecuador (Chevron Corporation and Texaco Petroleum Company v. The Republic of Ecuador (I), PCA Case No. 34877). In August 2018, the tribunal issued an award in favor of Chevron. See Chevron Corporation and Texaco Petroleum Company and The Republic of Ecuador (II), PCA Case No. 2009-23, Second Partial Award on Track II (August 30, 2018), paras. 9.22, 9.24 in particular. 
It is possible that the threat of arbitration might also influence domestic court rulings. One participant provided an example of a case in Guatemala, where a local community opposed a hydroelectric dam project through judicial proceedings. A court in Guatemala ruled that proper consultations had not been carried out, and suspended the project. The company reportedly threatened arbitration; ${ }^{16}$ a subsequent court ruling lifted the suspension, while acknowledging that consultation still had to be carried out. ${ }^{17}$

In addition to the potential for the international investment regime to undermine domestic or other claims brought by investment-affected rights holders, roundtable participants also discussed the possible effects of settlements of investor-state disputes. ${ }^{18}$ Participants noted the potential for negative impacts of settlement processes on access to justice if, for example, a state agrees to waive all claims against the investor as part of a settlement. Questions were raised by participants regarding the legal implications of waivers, the effects they may have on claims brought by third parties against investors, and whether such waivers might then be incompatible with the respective obligations and responsibilities of states and investors.

\section{Victimization and criminalization of community members}

Participants noted that community members involved in opposition to investment projects are often victimized by host states and investors, including by way of criminalization. Participants questioned whether the investment regime may exacerbate the potential for repression and criminalization of rights holders. For example, the high costs associated with investor-state arbitration, both material and reputational, may incentivize host states to crack down on opposition to international investments in order to avoid costly investor-state claims and even costlier liability. Indeed, tribunals have found governments liable for failure to protect an investment in the context of protests.

One example discussed by the group was Copper Mesa v. Ecuador, where participants noted that local communities have suffered victimization and criminalization based on their efforts to protect their rights and interests, and have so far been unable to access remedy for the harms they have suffered. Community members filed a lawsuit in Canada against the company and others, alleging that they suffered displacement, injuries, death threats, and other intimidation by private security forces hired by Copper Mesa; ${ }^{19}$ the case was eventually dismissed, with the dismissal affirmed by an appellate

16 “Hidroeléctrica Oxec podría recurrir a arbitraje internacional," El Periodico (April 28, 2017) <https://elperiodico.com.gt/inversion/2017/04/28/hidroelectrica-oxec-podria-recurrir-a-arbitraje-internacional/>.

17 "La Corte de Constitucionalidad de Guatemala le permite a la hidroeléctrica Oxec seguir trabajando," El Economista (May

27, 2017) <http://www.eleconomista.es/energia/noticias/8388042/05/17/La-Corte-de-Constitucionalidad-deGuatemala-le-permite-a-la-hidroelectrica-Oxec-seguir-trabajando.html>.

${ }_{18}$ For further discussion of the settlement of investor-state disputes, see Lise Johnson and Brooke Skartvedt Guven, "The Settlement of Investment Disputes: A Discussion of Democratic Accountability and the Public Interest," Investment Treaty News (March 13, 2017) <http://ccsi.columbia.edu/files/2017/03/ITN-The-Settlement-of-Investment-Disputes-Mar-132017.pdf>.

19 Ramirez and Ors v Copper Mesa Mining Corporation, TSX Inc, TSX Group Inc. and Ors. Statement of Claim, Ontario Superior Court of Justice (March 3, 2009) < http://www.ramirezversuscoppermesa.com/statement-of-claim.pdf $>$. 
court. They did win one small victory of sorts, although it did not amount to any form of remedy: the company was eventually delisted from the Toronto Stock Exchange (TSX).

\section{Allocation of state resources}

Participants noted that international investment law can lead states to prioritize the allocation of resources towards investor protection. Investment treaties can operate in a context where power asymmetries already exist: investors have access to and favorable attention from government, while communities are marginalized and forgotten, if not victimized. Thus, introducing a system in which the government feels that international law requires it to devote even more attention to the interests of investors is particularly problematic. One participant noted, for example, that material resources and political weight have often been dedicated to creating and maintaining high-level institutional structures that are specifically established to support and address the concerns of foreign investors. While this is not itself problematic, such allocation of resources might occur while human rights monitoring and enforcement bodies remain under-resourced, and local communities do not have a similarly powerful advocate within the government. The pressure that investor-state arbitration places on governments to respond to and resolve investor concerns therefore can (further) tilt allocation of state resources and power towards initiatives that support investors, and away from agencies or bodies that hear the concerns of and protect the interests of rights holders, an outcome that could negatively impact rights holders' access to justice.

\section{Regulatory chill and other disincentives}

Participants noted that investment treaties, and investor-state claims brought by investors on the basis of those agreements, can create a "chill" on the adoption or enforcement of regulations or other measures that may, directly or indirectly, have a negative impact on investments or otherwise affect the expectations of an investor. While investment treaties do not directly prohibit the adoption of measures necessary for a state to comply with its human rights obligations-and more recent treaties may include "right to regulate" clauses that purport to protect the regulatory flexibility needed by states to regulate in the public interest-these agreements can nevertheless discourage states from adopting or enforcing important regulations or measures.

While it is difficult to document the impacts of regulatory chill, participants pointed to examples of states adjusting policies in response to investor concerns, or to the threat of arbitration by investors. One participant provided the example of Indonesia, noting that the government reportedly backed down from introducing new environmental laws when companies threatened claims. ${ }^{20}$ Such anecdotal evidence also squares with observations from investment law insiders. ${ }^{21}$

20 When Indonesia attempted to ban open-pit mining in protected forests, mining companies threatened to launch
investment disputes under the Australia-Indonesia and UK-Indonesia BITs. Indonesia reportedly backed down and
exempted foreign investors from the proposed ban, despite analysis that the claims were unlikely to win. See Stuard G.
Gross, "Inordinate Chill: Bits, non-NAFTA MITs and Host-State Regulatory Freedom-An Indonesian Case Study." Mich. J. Int'l
L. 24: 893 2002, 895.
21 See, for example, David Schneiderman, Kyla Tienhaara, and Gus Van Harten, "Reply to EFILA," Investor-State Dispute
Settlement - C Comments and Cbservations: Gus Van Harten (July 6, 2015) 
With respect to the impact of regulatory chill that might affect access to justice for rights holders, participants noted that governments may be dissuaded from enacting regulations or otherwise taking actions that would increase access to justice in some way. If, for example, new environmental laws would provide greater redress mechanisms for environmental harms, then the decision not to enact such laws might result in fewer opportunities for redress.

Participants also noted that investment law protections might also make it more expensive or complicated for governments to enact progressive human rights measures that might be required as a remedy. For example, if a domestic court or human rights tribunal required the restitution of lands or territories, the government may be discouraged from complying with the determination if doing so could in turn result in an investor-state claim. Alternatively, the government might seek to comply in the narrowest way, which may limit the effectiveness of the remedy obtained.

\section{Reform Options Discussed}

Participants noted that multiple proposals for reform of the investment regime and strengthening of the human rights regime, particularly in the context of business-related abuses, have been advanced in recent years. With respect to the international investment regime, these proposals range from revising investment treaty standards to establishing an "investment court" or providing for alternatives to investor-state arbitration. With respect to the human rights regime, some stakeholders have argued for the adoption of a binding international instrument to regulate the activities of transnational corporations and other business enterprises with respect to human rights; others have advocated for the use of international arbitration to seek remedies for business-related human rights abuses. Many have increasingly emphasized the role that home states can and should play in ensuring that the rights of investment-affected people in the host state are respected, protected, and fulfilled. Calls for human rights impact assessments (HRIAs) of investment treaties have also become more common.

Building on discussions regarding the impacts of the investment regime on access to justice for rights holders, the second roundtable session was dedicated to a discussion of ways forward. In particular, participants sought to assess whether and to what extent existing proposals for reform were likely to address the implications of investment treaties and investor-state arbitration for rights holders' access to justice. The key takeaways below synthesize recommendations put forward during these discussions. Ideas discussed ranged from smaller adjustments to more ambitious reforms. Roundtable participants agreed that a number of efforts, achievable in the shorter and longer term, are needed to address the impacts of the investment regime on access to justice. Several participants also stressed the need for structural change to address the inequality inherent in the means and mechanisms available to investment-affected rights holders to access justice for abuses and

<https://gusvanharten.wordpress.com/2015/07/> (among other points, quoting Toby Landau, a leading arbitration attorney who stated that regulatory chill "definitely exists, and there's palpable evidence of it. There are those who deny it, but I can say that, in my role as counsel, on a number of occasions now, I've actually been instructed by governments to advise on possible adverse implications or consequences of a particular policy in terms of investor-state cases."). 
violations caused or exacerbated by international investments, as compared to the means and mechanisms available to investors to enforce investor protections under investment treaties.

\section{Explore informed alternatives to the current approach to investment protection}

Participants noted that, in recent years, several states have terminated their investment treaties and withdrawn from the Convention on the Settlement of Investment Disputes between States and Nationals of Other States (ICSID Convention). Bolivia, Ecuador, Indonesia, India, and South Africa, for example, have terminated some or all of their investment treaties in an effort to renegotiate these agreements from a clean slate and/or adopt alternative approaches to investment protection, including improvement of domestic frameworks applicable to inward investment. It was noted that States (such as Brazil) that have adopted alternative approaches to investment governance that do not provide for investor-state arbitration illustrate the potential for modes of investment governance that do not extend to investors the option of investor-state arbitration.

To the extent that the current model of investor-state arbitration under the investment law regime affects access to justice, the implementation of alternative approaches to investment protection that do not include an arbitration option provides an obvious way to address access-to-justice concerns. Participants underscored, however, the need for greater support for states that want to opt out of the traditional approach to investment protection in favor of other alternatives. In this regard, several participants highlighted the importance of political mobilization, noting the ways in which mobilization in certain countries has begun to shift public opinion and political calculations around investor-state arbitration.

\section{Reform investment treaty standards}

To the extent states continue to engage in concluding investment treaties, there are various options to consider. As noted above, one widely suggested option was to drop investor-state arbitration. If investor-state arbitration were not dropped, other options regarding reform of that mechanism were discussed. Whether or not investor-state arbitration is retained, participants noted that it will be critical to reform investment treaty standards. A number of suggestions were made in this regard.

Some participants noted that states should include provisions requiring compliance with human rights norms and standards in their investment treaties. These could include investor obligations regarding human rights due diligence and HRIAs, with reference to clear methodologies. Investors unable to establish compliance with human rights obligations could be precluded from treaty coverage and, if investor-state arbitration were included in the treaty, from raising claims against states.

For states interested in including specific investor obligations in investment treaties, one participant pointed to two model agreements - the South African Development Community (SADC) Model 
Bilateral Investment Treaty Template 22 and the International Institute for Sustainable Development (IISD) Model International Agreement on Investment for Sustainable Development. ${ }^{23}$ It was also mentioned that the Morocco-Nigeria BIT, which includes several provisions that mirror the SADC and IISD models, includes some provisions regarding investor obligations, and is notable for its departure from the traditional approach of including only voluntary investor commitments. This agreement explicitly provides for a number of investor obligations applicable to both the pre- and postestablishment phase of the investment, including regarding impact assessments, labor standards, and human rights. ${ }^{24}$

Other potential reforms discussed included narrowing the scope of protections provided to investors. It was noted, for instance, that aligning investment treaties with human rights law requires that states refrain from the inclusion of certain provisions, such as umbrella clauses that could be used to enforce stabilization provisions. Another suggestion was to add exception clauses that allow governments to derogate from investment treaties in certain circumstances. ${ }^{25}$

Participants also discussed ways in which treaties could be more effectively designed to address barriers in access to justice caused or exacerbated by business activities. Participants generally agreed, for example, on the importance of including treaty requirements regarding liability of investors in the home state; technical cooperation and capacity building programs to ensure host state courts can provide access to justice; and provisions regarding insurance or civil liability schemes, especially in the context of hazardous activities.

Regarding the suggestion for enhanced insurance protections, participants discussed the appropriateness of certain models of insurance protection, including political risk insurance, private insurance, or state insurance. One participant pointed out that such mechanisms may create obligations for insurers to respect human rights through the offering of new products. Another participant brought up the costs related to investment-related human rights violations and the possibility that companies already include such calculations when they conduct risk management. It was pointed out that an ILO Maritime Labour Convention had the impact of changing insurance schemes for enhanced human rights protection in the shipping industry. Participants generally agreed that further examination was needed to assess the applicability of similar approaches in the investment regime.

22 Model Bilateral Investment Treaty Template of the South African Development Community (2012), $<$ www.iisd.org/itn/wp-content/uploads/2012/10/sadc-model-bit-template-final.pdf>.

23 IISD Model International Agreement on Investment for Sustainable Development (April 2005), $<$ https://www.iisd.org/pdf/2005/investment model int agreement.pdf>.

24 Reciprocal Investment Promotion and Protection Agreement between the Government of the Kingdom of Morocco and the Government of the Federal Republic of Nigeria (signed 3 December 2016), arts 14-20.

25 For discussion of this option, see e.g., Barnali Choudhury, "Exception Provisions as a Gateway to Incorporating Human Rights Issues into International Investment Agreements" 59 Columbia Journal of Transnational Law, 670; Report of the Special Rapporteur on the Rights of Indigenous Peoples, UN doc A/HRC/33/42/E, August 11, 2016); CCSI, "Outcome Report of Workshop on International Investment and the Rights of Indigenous Peoples," November 16, 2017 <http://ccsi.columbia.edu/files/2016/11/Workshop-on-International-Investment-and-the-Rights-of-IndigenousPeoples-Outcome-Document-November-2016.pdf>. 


\section{Reform investor-state arbitration}

Where states choose to retain investor-state arbitration in investment treaties, steps taken to reform dispute settlement should address the impacts of the current approach on investment-affected rights holders.

Participants discussed, for example, the importance of transparency and participation of rights holders in investment negotiations and investor-state arbitration. One participant noted the importance of further efforts to promote transparency throughout arbitral proceedings. While some advances have been made in recent years, including the adoption of the UN Commission on International Trade Law (UNCITRAL) Rules on Transparency in Treaty-Based Investor-State Arbitration and the related "Mauritius Convention on Transparency," many investor-state claims continue to be determined behind closed doors, even if awards are eventually made public. Additionally, other arbitral institutions such as ICSID have yet to update their rules regarding transparency. ${ }^{26}$ Participants agreed that proceedings must be conducted in an open and transparent manner. Several participants suggested taking additional steps to make proceedings and case materials more accessible to those affected by the investor-state proceedings, including by translating materials and hearings into local language, and having hearings take place within the host country.

It was also said that, in cases when the rights or interests of a non-party are likely to be affected by the proceedings, that non-party should have the right to join as a party, and if such a party cannot be so joined, the proceedings should be dismissed.

Participants also discussed inclusion of treaty language expressly requiring investors to exhaust domestic remedies before seeking investor-state arbitration. It was said that this could, among other impacts, better ensure disputes are heard in domestic fora more accessible to a broader range of stakeholders. It was additionally suggested that investment treaties should contain language governing settlement, and preventing settlement of investor-state arbitration claims or counterclaims that purport to waive or determine claims of non-parties to the dispute. ${ }^{27}$

Participants also discussed concerns regarding the backgrounds and qualifications of arbitrators appointed to investor-state tribunals. Several participants noted the need for reform of rules regarding appointment of arbitrators to address concerns regarding impartiality and conflicts of interest. Suggestions were also made regarding changes to qualification criteria for arbitrators, including requirements for expertise in human rights law, in order to address broadly held concerns regarding determination of claims with human rights dimensions by those without expertise in

\footnotetext{
${ }^{26}$ For suggestions regarding reform of ICSID’s rules concerning transparency, see e.g, CCSI's Submission (March 31, 2017), pp. 2-4 <http://ccsi.columbia.edu/files/2017/04/ICSID-Rule-Revisions-Comment-31-March-17-FINAL.pdf>.

${ }_{27}$ For further discussion of settlements and counterclaims, see Lise Johnson and Brooke Skartvedt Guven, "The Settlement of Investment Disputes: A Discussion of Democratic Accountability and the Public Interest," Investment Treaty News (March 13, 2017) <http://ccsi.columbia.edu/files/2017/03/ITN-The-Settlement-of-Investment-Disputes-Mar-132017.pdf>.
} 
human rights law. Participants noted the importance of promoting greater inclusion of human rights law experts amongst the pool of arbitrators determining investor-state claims if human rights provisions are to be used to temper the impacts of investment treaties on the rights of third parties.

Related to these questions concerning who adjudicates the disputes, participants discussed the European Commission's proposed "investment court," noting concerns regarding the extent to which the proposal would address the actual or potential impacts of investment law on access to justice for investment-affected rights holders or, more generally, the broader criticisms regarding the illegitimacy and asymmetrical nature of the investment regime. Several participants noted that the court would continue to provide investors with a unique form of remedy at the international level, and would institutionalize many of the current failings of the regime, without expanding access to the mechanism to third parties. Moreover, referring to the mechanism as a "court" may lend legitimacy to a system that is not fundamentally different to investor-state arbitration, and could have an overall negative impact of crystallizing the current approach to investment protection.

Discussions of reform also included reference to ongoing dialogues in multilateral fora, including at UNCITRAL. In 2017, UNCITRAL's Working Group III began exploring possible reform of investorstate arbitration. ${ }^{28}$ One participant explained that UNCITRAL provides a forum for governments to negotiate rules on investor-state arbitration, and that states and civil society organizations with concerns about the system should follow and try to attend these meetings to have an impact on these discussions. ${ }^{29}$ Participants underscored the need to give a voice to investment-affected rights holders in the global dialogue on reform of the investment regime. Several participants also highlighted the need to link discussions taking place in human rights fora, including with respect to the draft binding instrument on transnational corporations and other business enterprises with respect to human rights, to discussions taking place in fora dedicated to reform of the investment regime. Other relevant processes include ICSID's efforts to revise its arbitration rules. ${ }^{30}$

\section{Empower rights holders}

It was widely noted that, absent significant changes to the international investment regime, rights holders' access to justice will continue to be at risk. There was thus a general consensus among participants that rights holders need to be empowered within the investment law framework. This would include greater transparency and access to information regarding investment treaty negotiations and disputes under concluded agreements, as well as corresponding opportunities for meaningful participation in the design of investment treaties and the conduct of investment disputes.

28 UNCITRAL, Working Group III, “2017 to present: Investor -State Dispute Settlement Reform” <http://www.uncitral.org/uncitral/en/commission/working groups/3Investor State.html>.

${ }^{29}$ For example, CCSI has made several submissions to UNCITRAL with recommendations regarding the rights and interests of non-parties, disclosure, terms of settlement, waiver, see CCSI, "Submissions to UNCITRAL Working Group II on Arbitration and Conciliation", <http://ccsi.columbia.edu/2013/02/05/submissions-to-uncitral-working-group-ii-onarbitration-and-conciliation/>.

30 CCSI submitted comments to the ICSID Secretariat regarding proposed revisions of the ICSID arbitration rules in March 2017. CCSI's submission is available here: http://ccsi.columbia.edu/2017/04/21/submission-regarding-amendments-tothe-icsid-arbitration-rules/. 
Greater transparency and access to information is only beneficial when such information can be used. Participants discussed ways in which communities could be supported in better understanding relevant investment rules and procedures, and their implications. Participants suggested that this could be achieved through workshops within communities that stand to be affected, as well as through the creation and provision of literature on the topic in relevant native languages. This could also include peer-to-peer learning, whereby communities that have already felt impacts of both investment projects and related investment arbitration or threats thereof could share their experiences and insights with other communities.

Participants suggested that citizens' rights to participate and be consulted in the context of investment treaty negotiations need to be strengthened. While this is not yet the norm for treaty negotiations in all countries, citizen participation and consultations should be effective, inclusive, and continuous; these should preferably take place before key decision-making stages in the investment treaty negotiation process.

\section{Develop and implement effective monitoring strategies}

Participants noted the importance of strengthening documentation of the impacts of investment projects on rights holders. Stronger documentation of investment projects can help create an evidence base that may be useful for affected rights holders that seek to challenge projects, and may also be relevant for investment disputes linked to the relevant projects. One community representative noted that the community with whom he worked began to document its situation as soon as a company moved onto its territory. This documentation greatly assisted the community in describing its interactions with the company and demonstrating the impact of the project. This was relevant when seeking to intervene in an ongoing investment arbitration.

Participants discussed various existing databases containing relevant information about investments and their impacts, and whether datasets could be merged in some way to provide a fuller picture of investment impacts. Stronger documentation of investment disputes and their impacts would also help clarify whether access to justice impacts would be addressed in specific proposals to modify investment and human rights legal regimes. Several participants noted the difficulties associated with documenting the impacts of the investment regime, including regulatory chill, and noted that much more could be done by researchers, civil society organizations, academia, and others in this regard. Participants suggested creating a database to support the tracking of specific impacts of investment treaties on, for example, social conflicts in a particular region. 


\section{Enhance human rights enforcement mechanisms}

Participants examined several ways to enhance enforcement of human rights law, including through claims in home states, and the ongoing effort to develop an international legally binding instrument to regulate the activities of transnational corporations and other business enterprises. Strengthening enforcement of the legal protections afforded by human rights law was seen to be critical. However, without sufficient reform of the investment regime itself, it is unclear how much such efforts could mitigate the investment regime's negative impacts on access to justice for rights holders.

\section{Break down silos}

Participants noted the need to raise awareness, amongst a range of stakeholders, of the investment regime's impacts on public policy, human rights, and access on justice. Similarly, participants pointed to the need to help break down silos amongst stakeholders. Such stakeholders include lawyers and others working within the investment law system, investors, rights holders, and policy makers. Those within the investment law system, for example, could benefit from greater awareness of the impacts of investment law and investment disputes on rights holders' access to justice. Similarly, if investors could be sensitized about negative impacts of their projects - which can play a role in community conflict and lead to eventual investor-state claims - these can be mitigated and avoided through careful project planning, negotiation, and implementation. Regarding rights holders, efforts to raise awareness of the impact of investment treaties on their rights and interests, as discussed above, could help them engage more meaningfully with other stakeholders on the question of potential reforms. For policy makers, improved awareness of the interconnectedness of international legal systems and related impacts could support more nuanced consideration of various reform options, and could also support their own efforts to address competing obligations.

\section{Conclusion}

The workshop reflected wide agreement among participants that actual or potential impacts of the investment law regime on access to justice for investment-affected rights holders further demonstrate the urgent need for reform of the investment regime and strengthening of accountability for business-related human rights abuses. Participants expressed concerns regarding whether the reform options proposed to date - both in terms of changes to the investment law system and initiatives to strengthen human rights law - would fully address the investment regime's impacts on access to justice. The discussion illustrated the need for further research on both impacts and solutions, and it clearly underscored the strong need for investment-affected rights holders to have an active voice in the discourse on these issues. 